\title{
Stable isotope geochemistry and phase equilibria of coesite-bearing whiteschists, Dora Maira Massif, western Alps
}

\author{
Z.D. Sharp, E.J. Essene*, and J.C. Hunziker \\ Institut de Minéralogie et Pétrographie, UNIL BFSH-2, CH-1015 Lausanne, Switzerland
}

Received July 20 1992/Accepted November 12, 1992

Abstract. Peak metamorphic temperatures for the
coesite-pyrope-bearing whiteschists from the Dora Maira
Massif, western Alps were determined with oxygen iso-
tope thermometry. The $\delta^{18} \mathrm{O}(\mathrm{smow})$ values of the quartz
(after coesite) $\left(\delta^{18} \mathrm{O}=8.1\right.$ to $8.6 \%$, $\left.n=6\right)$, phengite $(6.2$ to
$6.4 \%, n=3)$, kyanite $(6.1 \%, n=2)$, garnet (5.5 to $5.8 \%$,
$n=9)$, ellenbergerite $(6.3 \%, n=1)$ and rutile $(3.3$. to $3.6 \%$,
$n=3)$ reflect isotopic equilibrium. Temperature estimates
based on quartz-garnet-rutile fractionation are $700-$
$750{ }^{\circ} \mathrm{C}$. Minimum pressures are $31-32$ kb based on the
pressure-sensitive pyrope + coesite = kyanite + enstatite. In order to stabilize pyrope and coesite by the temperature-sensitive dehydration reaction talc + kyanite $=$ pyrope + coesite $+\mathrm{H}_{2} \mathrm{O}$, the $a\left(\mathrm{H}_{2} \mathrm{O}\right)$ must be reduced to $0.4-0.75$ at $700-750^{\circ} \mathrm{C}$. The reduced $a\left(\mathrm{H}_{2} \mathrm{O}\right)$ cannot be due to dilution by $\mathrm{CO}_{2}$, as pyrope is not stable at $X\left(\mathrm{CO}_{2}\right)>0.02\left(T=750^{\circ} \mathrm{C} ; P=30 \mathrm{~kb}\right)$. In the absence of a more exotic fluid diluent (e.g. $\mathrm{CH}_{4}$ or $\mathrm{N}_{2}$ ), a melt phase is required. Granite solidus temperatures are $\sim 680^{\circ} \mathrm{C} / 30 \mathrm{~kb}$ at $a\left(\mathrm{H}_{2} \mathrm{O}\right)=1.0$ and are calculated to be $\sim 70^{\circ} \mathrm{C}$ higher at $a\left(\mathrm{H}_{2} \mathrm{O}\right)=0.7$, consistent with this hypothesis. Kyanite-jadeite-quartz bands may represent a relict melt phase. Peak $P-T-f\left(\mathrm{H}_{2} \mathrm{O}\right)$ estimates for the whiteschist are $34 \pm 2 \mathrm{~kb}, 700-750^{\circ} \mathrm{C}$ and $0.4-0.75$. The oxygen isotope fractionation between quartz $\left(\delta^{18} \mathrm{O}=11.6 \%\right)$ and garnet $\left(\delta^{18} \mathrm{O}=8.7 \%\right)$ in the surrounding orthognesiss is identical to that in the coesitebearing unit, suggesting that the two units shared a common, final metamorphic history. Hydrogen isotope measurements were made on primary talc and phengite $\left(\delta \mathrm{D}_{(\mathrm{SMOW})}=-27\right.$ to $\left.-32 \%\right)$, on secondary talc and chlorite after pyrope $(\delta \mathrm{D}=-39$ to $-44 \%)$ and on the surrounding biotite $(\delta \mathrm{D}=-64 \%)$ and phengite $(\delta \mathrm{D}=-44 \%$ o gneiss. All phases appear to be in nearequilibrium. The very high $\delta \mathrm{D}$ values for the primary hydrous phases is consistent with an initial oceanicderived/connate fluid source. The fluid source for the

\footnotetext{
* Present address: Department of Geological Sciences, 1006 C.C. Little Bldg., University of Michigan, Ann Arbor, MI 4809-1063, USA

Correspondence to: Z.D. Sharp
}

retrograde talc + chlorite after pyrope may be fluids evolved locally during retrograde melt crystallization. The similar $\delta \mathrm{D}$, but dissimilar $\delta^{18} \mathrm{O}$ values of the coesitebearing whiteschists and hosting orthogneiss suggest that the two were in hydrogen isotope equilibrium, but not oxygen isotope equilibrium. The unusual hydrogen and oxygen isotope compositions of the coesite-bearing unit can be explained as the result of metasomatism from slab-derived fluids at depth.

\section{Introduction}

The identification of coesite in whiteschists of the southern Dora Maira Massif by Chopin (1984) is certainly one of the more remarkable discoveries in metamorphic petrology in the last decade. The ultra-high pressures indicated by the coesite are far greater than previously documented and significantly expand our knowledge of the maximum depths from which tectonic exhumation of metamorphic material can occur. Chesnokov and Popov (1965) first alluded to the possibility of quartz pseudomorphs after coesite in regional metamorphic rocks, but it was the positive identification by Chopin that stimulated numerous additional discoveries of coesite or quartz pseudomorphs after coesite (Smith 1984; Smith and Lappin 1987; Okay et al. 1989; Wang et al. 1989; Yang and Smith 1989; Enami and Zang 1990; Tagiri and Bakirov 1990; Hirajima et al. 1991; Reinecke 1991; Schmädicke 1991). The discovery of diamond inclusions in metamorphic garnets (Sobolev and Shatsky 1990; Shutong et al. 1992) is even more remarkable. The presence of coesite and diamond in metamorphic rocks defines a new "ultra-high pressure" metamorphic facies. As these rocks represent the known depth limits of in situ metamorphic material now exposed at the Earth's surface, accurate determinations of the peak metamorphic pressure, temperature and fluid composition associated with the metamorphic event are essential for understanding metamorphic processes in the deepest crustal regimes. 
Coesite-bearing whiteschists from Dora Maira have been extensively studied (Vialon 1966; Chopin 1984, 1986, 1987; Rossman et al. 1989; Chopin et al. 1991; Monié and Chopin 1991; Kienast et al. 1991; Schertl et al. 1991; Tilton et al. 1991). Metamorphic pressures of these coesitepyrope whiteschists are constrained by the preservation of coesite, the $\mathrm{Si}$ content in phengite (Massonne and Schreyer 1989), and the equilibrium assemblage pyrope + coesite in place of the lower pressure equivalent enstatite + kyanite (this study). The temperatures of metamorphism are more poorly constrained. The best temperature constraint comes from the univariant equilibrium:

$$
\begin{aligned}
& \mathrm{Mg}_{3} \mathrm{Si}_{4} \mathrm{O}_{10}(\mathrm{OH})_{2}+\mathrm{Al}_{2} \mathrm{SiO}_{5}=\mathrm{Mg}_{3} \mathrm{Al}_{2} \mathrm{Si}_{3} \mathrm{O}_{12}+2 \mathrm{SiO}_{2}+\mathrm{H}_{2} \mathrm{O} \\
& \text { talc kyanite pyrope coesite }
\end{aligned}
$$

Reaction (1) has been experimentally calibrated (Chopin 1985), but temperature estimates based on this reaction require an accurate knowledge of the $\mathrm{H}_{2} \mathrm{O}$ activity $\left[a\left(\mathrm{H}_{2} \mathrm{O}\right)\right]$ attending metamorphism. Chopin (1984) proposed that temperatures were somewhere between 700 and $800{ }^{\circ} \mathrm{C}$ depending upon the $\mathrm{H}_{2} \mathrm{O}$ activity. In this study, temperatures were estimated from oxygen isotope thermometry, a thermometric technique that is nominally independent of $\mathrm{H}_{2} \mathrm{O}$ activity. The coesite-bearing assemblage is well suited for oxygen isotope thermometry and unlikely to have undergone retrograde reequilibration as (1) the mineral phases are refractory, (2) the rock was cooled rapidly and, as concluded in this study, (3) the $a\left(\mathrm{H}_{2} \mathrm{O}\right)$ was low during peak and early retrograde metamorphism. The isotopic data not only allow $P-T$ estimates to be made, but also can be used in conjunction with mineral equilibria data to constrain the composition of the fluid phase accompanying metamorphism.

\section{Geology and mineralogy of the coesite-bearing rocks}

Coesite-bearing rocks and surrounding gneisses sampled in this study are from the Parigi outcrop, near Martiniana Po, Italy. This outcrop has been described in great detail (Vialon 1966; Chopin 1984; Chopin et al. 1991; Schertl et al. 1991), so that only relevant features are described in this section. The coesite bearing whiteschists are preserved as boudins up to $90 \mathrm{~m}$ in length and several tens-of-meters thick hosted in a phengite-biotite gneiss. The whiteschist is thought to have a protolith of Proterozoic age (Paquette et al. 1989; Tilton et al. 1989) and underwent high pressure metamorphism with a low geothermal gradient during the early Alpine orogeny (Monié and Chopin 1991; Tilton et al. 1991). The whiteschist boudins can be divided into three types: a fine-grained quartzite with small pyrope porphyroblasts; a talc-phengite-kyanitequartz matrix with pyrope megacrysts and an occasional kyanitejadeite-quartz-rich layer or vein.

A summary of the mineralogy of the Parigi rocks is given by Schertl et al. (1991), who listed over 20 minerals in the coesitebearing unit. The modally abundant phases are quartz, kyanite, talc, pyrope, phengite, with minor rutile (inclusions in garnet and matrix) and the new mineral ellenbergerite (inclusions in large garnets only). Chlorite is found as a relict prograde mineral in pyrope megacrysts and as a late alteration product. Coesite is found most commonly as inclusions in the small pyropes in the quartzite layers and almost never in the groundmass. Phases notably absent include enstatite and phlogopite, the latter having been found only as an inclusion within a kyanite inclusion in pyrope (Schertl et al. 1991). The surrounding biotite-phengite gneiss is composed predominantly of quartz, plagioclase, microcline, biotite and phengite, with minor chlorite, garnet, epidote, tourmaline and sphene (Schertl et al. 1991).

\section{Previous pressure-temperature estimates of Dora Maira whiteschists}

Chopin (1984) was the first to document ultra-high pressures of regional metamorphism for the Dora Maira whiteschists based primarily on the presence of coesite. Chopin (1984) also recognized that the assemblage phengite + pyrope is the high pressure product of the reaction:

$$
\begin{gathered}
6 \mathrm{KMg}_{3} \mathrm{AlSi}_{3} \mathrm{O}_{10}(\mathrm{OH})_{2} \\
\text { phlogopite }
\end{gathered}
$$

Temperatures of metamorphism were constrained with reaction (1), although, as pointed out by Chopin, exact temperatures depend upon assumed $\mathrm{H}_{2} \mathrm{O}$ activity. Chopin (1984) concluded that water activities were above 0.2 , temperatures were slightly higher than $700^{\circ} \mathrm{C}$, and pressures were greater than $28 \mathrm{~kb}$. More recent temperature estimates range between 700 and $800^{\circ} \mathrm{C}$. Estimates of $700^{\circ} \mathrm{C}$ have been proposed based on the lack of textural evidence for partial melting of the country rocks (Chopin 1987). The most recent $P-T$ estimates are $37 \mathrm{~kb}$ and $800^{\circ} \mathrm{C}$, based on the intersection of the isopleth for the Si-content in phengite with reaction (1), and assuming unit $\mathrm{H}_{2} \mathrm{O}$ activity (Schert et al. 1991).

\section{Sample description}

Five samples from the coesite-bearing unit and one from the enclosing orthogneiss were analyzed. Two samples of pyrope megacrysts were analyzed. Sample $P M-I$ was a $10 \mathrm{~cm}$ diameter megacryst that was crushed in order to separate the mineral inclusions quartz, rutile, kyanite, phengite, ellenbergerite and talc. A phyllosilicate rind existed on this garnet before crushing, so that some of the phengite may not have been included in the garnet. Sample $P M-2$ was a 50 $60 \mathrm{~mm}$ diameter garnet megacryst for which only the garnet was analyzed. Sample GM-1 is a garnet megacryst layer. All mineral separates analyzed in this sample other than garnet were from the matrix. Sample $Q Z T-1$ is a quartzite (coesitite notation of Chopin 1984) layer-with small, coesite-bearing garnets. The garnet and the quartz matrix were analyzed. Sample $A P-I$ was a completely altered $30 \mathrm{~mm}$ diameter pyrope megacryst found in a stream bed. The sample is now a finite-grained greenish intergrowth of kyanite, talc and quartz after pyrope. Sample $A S-l$ is a two-mica orthogneiss taken from the surrounding orthogneiss containing minor garnet.

\section{Analytical methods}

Rock samples were crushed, sieved and ultrasonically cleaned. Mineral separates were made with a combination of heavy liquid techniques, magnetic separation and final hand picking. Quartz was separated from feldspar in the gneiss sample AS 1 by briefly reacting the bimineralic concentrate in hydrofluoric acid. The product was gently ground to disintegrate the feldspar, leaving only pure quartz as a residual phase. Virtually pure mineral separates of $1-2 \mathrm{mg}$ could be achieved by these methods.

Oxygen isotope values of mineral separates were determined with the laser-based extraction method (Sharp 1990; 1992). Analyses were made on $\sim 1 \mathrm{mg}$ of material. A maximum of 17 samples could be loaded simultaneously on a nickel sample holder and placed in the reaction chamber. Three to four standards were analyzed in each run. All samples were analyzed at least twice (except ellenbergerite, due to the rarity of this phase). Samples were heated with a $\mathrm{CO}_{2}$ laser in $\mathrm{a}_{\mathrm{Br}} \mathrm{F}_{5}$ atmosphere to quantitatively liberate oxygen. The oxygen was separated from the excess reagent cryogenically and then passed over a mercury diffusion pump to remove traces of $F_{2}$. The $\mathrm{O}_{2}$ was converted to $\mathrm{CO}_{2}$ by combustion with a heated graphite rod with a platinum catalyst and introduced directly into the mass spectrometer. 
Hydrogen isotope ratios and water contents were determined on hydrous mineral separates following procedures of Vennemann and O'Neil (1993). Analyses were made by placing $20-40 \mathrm{mg}$ of a purified mineral in a silica-glass tube. After evacuation, the samples were heated with a gas-oxygen flame until the minerals melted. $\mathrm{All}_{2} \mathrm{O}$ was collected on a cold trap during melting. Minor $\mathrm{H}_{2}$ produced during heating was converted to $\mathrm{H}_{2} \mathrm{O}$ by reaction with a $\mathrm{CuO}$ furnace at $550^{\circ} \mathrm{C}$. The two sources of $\mathrm{H}_{2} \mathrm{O}$ were combined, cryogenically purified, and frozen into Pyrex tubes with excess zinc. The tubes were sealed and heated at $450^{\circ} \mathrm{C}$ for 20 minutes, quantitatively reducing $\mathrm{H}_{2} \mathrm{O}$ to $\mathrm{H}_{2}$ by reaction with zinc. Thew $\delta \mathrm{D}$ value and the water content were determined with the mass spectrometer, the latter being determined from the mass 2 voltage for a constant volume.

\section{Results}

Oxygen and hydrogen isotopic values of mineral separates from the coesite-bearing whiteschist and the surrounding orthogneiss are given in Table 1 . The $\delta^{18} \mathrm{O}$ values of all phases are homogeneous in hand sample and are nearly constant within the entire whiteschist body. Isotopic equilibrium was attained on a scale approaching $>100 \mathrm{~m}$ regardless of bulk composition. For example, the total range of garnet analyses is 5.45 to $5.81 \%$, and only 5.45 to $5.57 \%$ if sample PM-2 is excluded. The entire coesitebearing unit has reached internal oxygen isotope equilibrium, but not with the surrouding orthogneiss. The $\delta{ }^{18} \mathrm{O}_{\text {(quartz) }}$ value of the two-mica gneiss is $3 \%$ higher than in the coesite-bearing rocks.

Equilibrium temperatures based on the oxygen isotope fractionation between the minerals quartz, garnet and rutile were calculated with experimental, empirical and theoretical calibrations (Table 2). Temperature estimates for the coesite-bearing unit based on experimental calibrations range from $700-750^{\circ} \mathrm{C}$; those based on empirical calibrations have only a slightly larger temperature spread. The theoretical calibrations of Hoffbauer et al. (1993) based on the increment method yield somewhat higher temperatures. The estimates of Hoffbauer appear in some cases to yield excessively high temperatures (Sharp et al. 1992), and are not preferred. Temperature estimates for the garnet orthogneiss from the $\Delta$ (quartzgarnet) fractionations are identical to those of the coesitebearing unit. Biotite in the orthogneiss is clearly out of isotopic equilibrium with the more refractory minerals quartz and garnet. This result is expected, as biotite is also out of textural equilibrium and most likely was crystallized in a later, low-pressure metamorphism (Monié and Chopin 1991).

The degree of isotopic equilibrium between all phases in the coesite-bearing unit was assessed with the graphical method of Javoy et al. (1970) and the theoretical fractionation factors of Hoffbauer et al. (1993). In addition to the fractionation factors published in Hoffbauer et al. (1992), $R$. Hoffbauer has kindly calculated the fractionation factor for ellenbergerite $\left(\mathrm{I}^{18} \mathrm{O}_{\text {ellenbergerite }}=0.71\right.$ based on $60 \%$ bridging hydrogen, where $\mathrm{I}^{18} \mathrm{O}_{\text {quartz }}=1.00 ; \mathrm{I}=$ increment index of Hoffbauer et al. 1993). The linear fit of the $\delta^{18} \mathrm{O}$ values for each mineral versus the temperature coefficient of fractionation $a$ from the equation

$1000 \ln \alpha=a \times 10^{6} \times T^{-2}$
Table 1. Oxygen and hydrogen isotopic composition of mineral separates

\begin{tabular}{|c|c|c|c|c|c|}
\hline Mineral & $\begin{array}{l}\delta^{18} \mathrm{O} \\
\text { (SMOW) }\end{array}$ & $\begin{array}{l}\text { Mass } \\
(\mathrm{mg})\end{array}$ & $\begin{array}{l}\text { Analysis } \\
\text { Number }\end{array}$ & $\begin{array}{l}\delta \mathrm{D} \\
\text { (SMOW) }\end{array}$ & $\begin{array}{l}\text { Sample } \\
\text { Name }\end{array}$ \\
\hline \multicolumn{6}{|c|}{ Coesite-bearing unit } \\
\hline Quartz & $\begin{array}{l}8.42 \\
8.65 \\
8.10 \\
8.30 \\
8.31 \\
8.47\end{array}$ & $\begin{array}{l}1.03 \\
1.14 \\
1.13 \\
1.70 \\
1.34 \\
1.48\end{array}$ & $\begin{array}{l}\text { S089-3 } \\
\text { S090-3 } \\
\text { S092-4 } \\
\text { S093-3 } \\
\text { S099-6 } \\
\text { S099-7 }\end{array}$ & & $\begin{array}{l}\text { PM-1 } \\
\text { PM-1 } \\
\text { GM-1 } \\
\text { GM-1 } \\
\text { QZT-1 } \\
\text { QZT-1 }\end{array}$ \\
\hline Garnet & $\begin{array}{l}5.57 \\
5.80 \\
5.81 \\
5.55 \\
5.45 \\
5.48 \\
5.54 \\
5.50 \\
5.53\end{array}$ & $\begin{array}{l}1.17 \\
1.39 \\
1.46 \\
1.13 \\
1.49 \\
1.60 \\
1.64 \\
1.23 \\
1.35\end{array}$ & $\begin{array}{l}\text { S090-4 } \\
\text { S098-10 } \\
\text { S098-11 } \\
\text { S092-5 } \\
\text { S092-6 } \\
\text { S093-4 } \\
\text { S093-6 } \\
\text { S098-12 } \\
\text { S098-13 }\end{array}$ & & $\begin{array}{l}\text { PM-1 } \\
\text { PM-2 } \\
\text { PM-2 } \\
\text { GM-1 } \\
\text { GM-1 } \\
\text { GM-1 } \\
\text { GM-1 } \\
\text { QZT-1 } \\
\text { QZT-1 }\end{array}$ \\
\hline Rutile & $\begin{array}{l}3.60 \\
3.50 \\
3.32\end{array}$ & $\begin{array}{l}1.00 \\
1.96 \\
1.38\end{array}$ & $\begin{array}{l}\text { S089-8 } \\
\text { S093-12 } \\
\text { S093-13 }\end{array}$ & & $\begin{array}{l}\text { PM-1 } \\
\text { GM-1 } \\
\text { GM-1 }\end{array}$ \\
\hline Kyanite & $\begin{array}{l}6.08 \\
6.12\end{array}$ & $\begin{array}{l}0.80 \\
1.52\end{array}$ & $\begin{array}{l}\text { S089-7 } \\
\text { S093-14 }\end{array}$ & & $\begin{array}{l}\text { PM-1 } \\
\text { GM-1 }\end{array}$ \\
\hline Phengite & $\begin{array}{l}6.33 \\
6.20 \\
6.41\end{array}$ & $\begin{array}{l}2.15 \\
1.73 \\
1.19\end{array}$ & $\begin{array}{l}\text { S089-5 } \\
\text { S089-6 } \\
\text { S093-8 }\end{array}$ & -35 & $\begin{array}{l}\text { PM-1 } \\
\text { PM-1 } \\
\text { GM-1 }\end{array}$ \\
\hline Ellenbergerite & 6.31 & 0.75 & S089-11 & & PM-1 \\
\hline Talc & - & - & - & -32 & PM-1 \\
\hline Altered pyrope & $\begin{array}{l}4.51 \\
4.73\end{array}$ & $\begin{array}{l}1.09 \\
2.39\end{array}$ & $\begin{array}{l}\text { S115-1 } \\
\text { S1 15-2 }\end{array}$ & -42 & $\begin{array}{l}A P-1 \\
A P-1\end{array}$ \\
\hline \multicolumn{6}{|c|}{ Enclosing orthogneiss } \\
\hline Quartz & $\begin{array}{l}11.46 \\
11.56 \\
11.88 \\
11.50\end{array}$ & $\begin{array}{l}3.20 \\
2.97 \\
1.79 \\
1.92\end{array}$ & $\begin{array}{l}\text { S111-6 } \\
\text { S112-3 } \\
\text { S112-4 } \\
\text { S112-5 }\end{array}$ & & $\begin{array}{l}\text { AS-1 } \\
\text { AS-1 } \\
\text { AS-1 } \\
\text { AS-1 }\end{array}$ \\
\hline Garnet & $\begin{array}{l}8.85 \\
8.66\end{array}$ & $\begin{array}{l}1.24 \\
1.60\end{array}$ & $\begin{array}{l}\text { S111-4 } \\
\text { S111-5 }\end{array}$ & & $\begin{array}{l}\text { AS-1 } \\
\text { AS-1 }\end{array}$ \\
\hline $\begin{array}{l}\text { Biotite } \\
\text { Phengite }\end{array}$ & $\begin{array}{c}6.78 \\
-\end{array}$ & $\begin{array}{c}1.59 \\
-\end{array}$ & S111-8 & $\begin{array}{l}-64 \\
-44\end{array}$ & $\begin{array}{l}\text { AS-1 } \\
\text { AS-1 }\end{array}$ \\
\hline
\end{tabular}

a Talc, kyanite and chlorite (reaction 3 in text)

where $1000 \ln \alpha \approx \delta_{x}-\delta_{y}$ (phases $x$ and $y$ ), indicates that all minerals have achieved and maintained isotopic equilibrium (Fig. 1). The slope of the best-fit line in Fig. 1 is proportional to the temperature of equilibrium by Eq. 3 . Temperature estimates based on mineral inclusions in garnet megacrysts and groundmass minerals are identical, within experimental error. This result suggests that garnet megacrysts grew at or near peak metamorphic temperatures, or that complete equilibrium was attained by the process of intracrystalline diffusion at the peak of metamorphism. Ellenbergerite is also in apparent isotopic equilibrium with garnet and quartz, even though it is thought to be a prograde relict mineral, not stable at the peak of metamorphism (Chopin 1986). The uncertainties in the calculations for the fractionation factors are suffi- 
Table 2. Temperature $\left({ }^{\circ} \mathrm{C}\right)$ estimates based on the $\delta^{18} \mathrm{O}$ fractionations between coexisting phases

\begin{tabular}{|c|c|c|c|c|c|c|c|c|}
\hline \multirow[b]{2}{*}{ Sample } & \multicolumn{3}{|c|}{ Experimental calibration } & \multicolumn{5}{|c|}{ Empirical calibration } \\
\hline & $\Delta \mathrm{Qz}-\mathrm{Gt}$ & $\Delta Q z-R u$ & $\Delta \mathrm{Gt}-\mathrm{Ru}$ & $\Delta \mathrm{Qz}-\mathrm{Gt}$ & $\Delta \mathrm{Qz}-\mathrm{Ru}$ & $\Delta \mathrm{Gt}-\mathrm{Ru}$ & $\Delta Q z-B i$ & $\Delta \mathrm{Gt}-\mathrm{Bi}$ \\
\hline PM-1 & 710 & 740 & 720 & 720 & 710 & 710 & - & - \\
\hline GM-1 & 750 & 750 & 700 & 760 & 720 & 680 & - & - \\
\hline QZ-1 & 730 & - & - & 740 & - & - & - & - \\
\hline $\mathrm{AS}-1$ & 720 & - & - & 730 & - & - & 550 & 290 \\
\hline \multicolumn{9}{|c|}{ Theoretical calibration } \\
\hline Sample & $\Delta \mathrm{Qz}-\mathrm{Gt}$ & $\Delta Q z-R u$ & $\Delta \mathrm{Qz}-\mathrm{Ph}$ & $\Delta Q z-K y$ & $\Delta \mathrm{Qz}-\mathrm{El}$ & $\Delta \mathrm{Gt}-\mathrm{Ru}$ & $\Delta \mathrm{Gt}-\mathrm{Ky}$ & $\Delta \mathrm{Gt}-\mathrm{El}$ \\
\hline PM-1 & 770 & 750 & 740 & 820 & 760 & 720 & 560 & 770 \\
\hline GM-1 & 820 & 760 & 870 & 900 & - & 700 & 460 & - \\
\hline QZ-1 & 780 & - & - & - & - & - & - & - \\
\hline
\end{tabular}

Sources of data: experimental $\Delta \mathrm{Qz}-\mathrm{Gt}$, Lichtenstein and Hoernes 1992; $\Delta \mathrm{Qz}-\mathrm{Ru}, \Delta \mathrm{Gt}-\mathrm{Ru}$, Matthews 1992. Empirical, $\Delta \mathrm{Qz}-\mathrm{Gt}$, $\Delta \mathrm{Qz}-\mathrm{Bi}, \Delta \mathrm{Gt}-\mathrm{Bi}$, Bottinga and Javoy 1975; $\Delta \mathrm{Qz}-\mathrm{Ru}$, Agrinier 1991; $\Delta \mathrm{Gt}-\mathrm{Ru}$, Bottinga and Javoy 1975; Agrinier 1991. Theoretical, Hoffbauer et al. 1993. Abbreviations: Bi, biotite; El, ellenbergerite; Gt, garnet; Ph, phengite; Qz, quartz; Ru, rutile

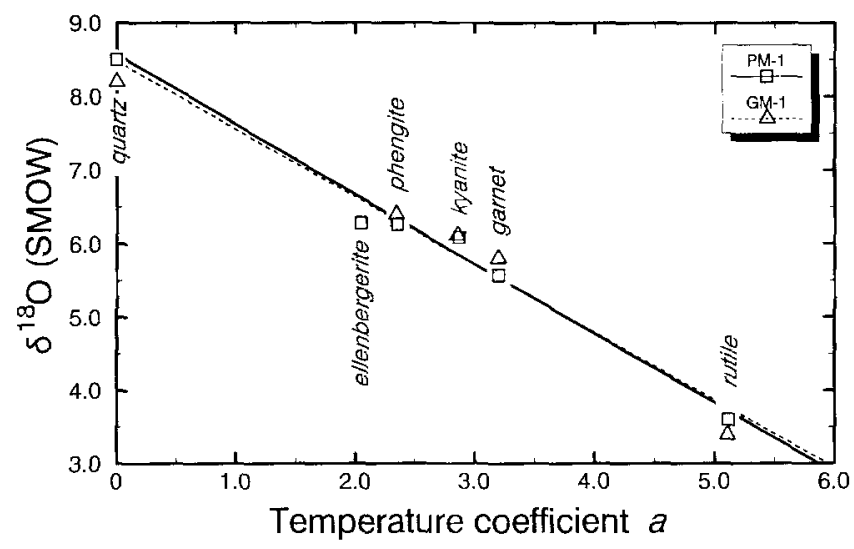

Fig. 1. A plot of the $\delta^{18} \mathrm{O}$ values for mineral separates of samples PM-1 (pyrope megacryst and inclusions) and GM-1 (pyrope megacryst and groundmass) versus the fractionation temperature coefficient $a(\mathrm{Eq} .3)$. The relationship between $\delta^{18} \mathrm{O}$ and $a$ must be linear if all phases are in equilibrium. (Fractionation coefficients from Hoffbauer et al. 1993)

ciently large so that the apparent peak-temperature equilibration may be fortuitous, although reequilibration at peak temperature by solid state diffusion is not unlikely.

Several lines of evidence argue that the oxygen isotope temperatures were not partially reset during cooling. First, the temperature estimates are indistinguishable between the garnet megacrysts and the matrix. If either of these distinct micro-environments partially reset, then the temperature estimates would be different. Second, the diffusion rates in garnet, kyanite, and to a lesser extent in quartz are very slow, and oxygen diffusion rates are even slower under anhydrous conditions (e.g. Farver and Yung 1991). The rocks are also thought to have cooled rapidly (Monié and Chopin 1991), so that the possibility of retrograde exchange is minimized. Finally, all minerals appear to be in isotopic equilibrium (Fig. 1). As the diffusion rate for each phase is different, it is very unlikely that all phases would undergo partial reequilibration and still maintain apparent equilibrium.

\section{Discussion}

Comparison with phase equilibria-P-T-a $\left(\mathrm{H}_{2} \mathrm{O}\right)$

The oxygen isotope temperature estimates for the Dora Maira rocks are $700-750^{\circ} \mathrm{C}$. These data can be combined with phase equilibria constraints to estimate fluid fugacities and the probability of whether or not partial melting occurred. In order to make these comparisons, it is first necessary to develop an internally consistent thermodynamic data base for generation of a petrogenetic grid in the system $\mathrm{K}_{2} \mathrm{O}-\mathrm{MgO}-\mathrm{Al}_{2} \mathrm{O}_{3}-\mathrm{SiO}_{2}-\mathrm{H}_{2} \mathrm{O}$

Two large, internally consistent thermodynamic data sets have been generated that are applicable to metamorphic rocks (Berman 1988; Holland and Powell 1990). The stability fields of reactions (1) and the following three experimentally constrained reactions were calculated with these data bases:

$$
\begin{aligned}
& 3 \mathrm{MgSiO}_{3}+\mathrm{Al}_{2} \mathrm{SiO}_{5}=\mathrm{Mg}_{3} \mathrm{Al}_{2} \mathrm{Si}_{3} \mathrm{O}_{12}+\mathrm{SiO}_{2} \\
& \text { enstatite kyanite pyrope coesite } \\
& \mathrm{Mg}_{3} \mathrm{Si}_{4} \mathrm{O}_{10}(\mathrm{OH})_{2}=3 \mathrm{MgSiO}_{3}+\mathrm{SiO}_{2}+\mathrm{H}_{2} \mathrm{O} \\
& \text { talc enstatite coesite } \\
& 2 \mathrm{Mg}_{3} \mathrm{Si}_{4} \mathrm{O}_{10}(\mathrm{OH})_{2}+4 \mathrm{Al}_{2} \mathrm{SiO}_{5}+3 \mathrm{Mg}_{5} \mathrm{Al}_{2} \mathrm{Si}_{3} \mathrm{O}_{10}(\mathrm{OH})_{8} \\
& \text { talc kyanite chlorite } \\
& =7 \mathrm{Mg}_{3} \mathrm{Al}_{2} \mathrm{Si}_{3} \mathrm{O}_{12}+14 \mathrm{H}_{2} \mathrm{O} \\
& \text { pyrope }
\end{aligned}
$$

The results from the two data sets are in excellent agreement but unfortunately do not reproduce the experimentally derived $P-T$ locations for these reactions. The stability fields for reactions (1), (4), (5) and (6), calculated with the Holland and Powell data set and the computer program of Powell and Holland (1988), are plotted in Fig. 2 along with the experimentally determined reversals for these reactions. The agreement between the experimental and the computed univariant equilibria is poor. The discrepancy for reaction (4) is due to solid solution of $\mathrm{Mg}$-Tschermak component ( $\mathrm{MgTs}$ ) in enstatite by the reaction

$\mathrm{MgSiO}_{3}+\mathrm{Al}_{2} \mathrm{SiO}_{5}=\mathrm{MgAl}_{2} \mathrm{SiO}_{6}+\mathrm{SiO}_{2}$ 


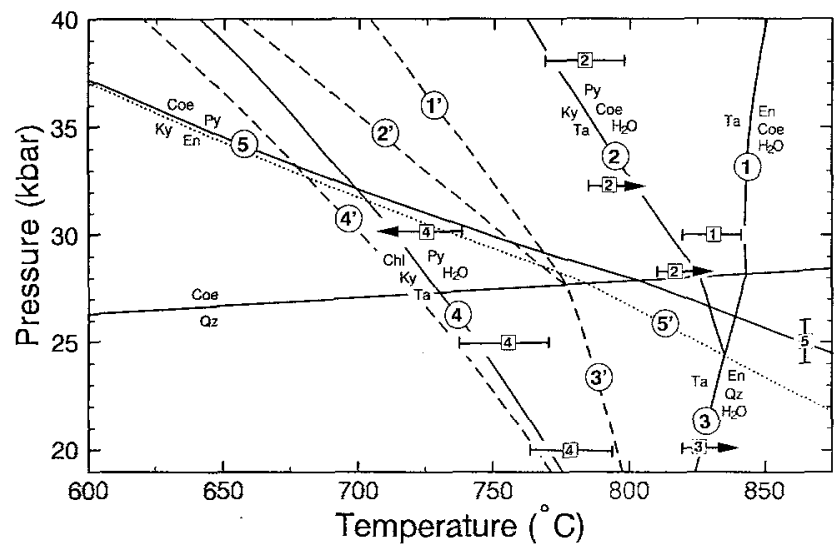

Fig. 2. Selected phase relations in the $\mathrm{MgO}-\mathrm{Al}_{2} \mathrm{O}_{3}-\mathrm{SiO}_{2}-\mathrm{H}_{2} \mathrm{O}$ system calculated with talc compressibility factor $(\beta)$ of $2.42 \mathrm{Mb}^{-1}$ (solid lines, labels and numbers) and $1.69 \mathrm{Mb}^{-1}$ (dashed lines and numbers followed by '). The $\beta$-value of $1.69 \mathrm{Mb}^{-1}$ from Holland and Powell (1990) does not reproduce the experimental reversals. The value of $2.42 \mathrm{Mb}^{-1}$ adequately reproduces all experiments involving talc. The solid curve for reaction 5 is corrected for the MgTs component in enstatite using the relationship of Gasparik and Newton (1984); the dotted curve is not. (Source of experiments: 1, 3, Kitahara et al. (1966); 2, 4, Chopin (1985); 5, Massonne (1983). Abbreviations for all figures $\mathrm{Cel}$, celadonite; $\mathrm{Chl}$, chlorite; $\mathrm{Coe}$, coesite; $\mathrm{Dm}$, diamond; $E n$, enstatite; $G r$, graphite; $J d$, jadeite; $K y$, kyanite; $l$, liquid; Mag, magnesite; $M u s$, muscovite; OrH, KAlSi ${ }_{3} \mathrm{O}_{8} \cdot \mathrm{H}_{2} \mathrm{O} ; P_{y}$, pyrope; $Q z$, quartz; $T a$, talc

and

$2 \mathrm{MgSiO}_{3}+\mathrm{MgAl}_{2} \mathrm{SiO}_{6}=\mathrm{Mg}_{3} \mathrm{Al}_{2} \mathrm{Si}_{3} \mathrm{O}_{12}$

enstatite $\mathrm{MgTs}$ pyrope.

Correction for the dilution of enstatite by $\mathrm{MgTs}$ buffered by pyrope was made with the experimental data for reaction (4) (Perkins et al. 1981; Gasparik and Newton 1984). The experiments for reaction (4) (Massonne 1983) and the calculated position of this reaction corrected for solid solution are in perfect agreement (Fig. 2).

All talc-bearing reactions are fit well with the Holland and Powell data set at pressures below $20 \mathrm{~kb}$. Only the high pressure reactions are in poor agreement with the experimentally determined stabilities. The effect of pressure increases the discrepancy between the calculated and measured stability relations for talc, suggesting that the compressibility data for talc in the large data sets may be inappropriate for high pressure phase equilibria.

The compressibility of talc is expressed by Holland and Powell as a single variable. This unfortunately does not allow for second order effects to be considered in the computer program of Powell and Holland (1988), even though the compressibility of talc is strongly non-linear (Vaidya et al. 1973). Agreement between the high pressure experiments and calculated equilibria occurs if the compressibility $(\beta)$ of talc is shifted to a value of $2.42 \mathrm{Mb}^{-1}$, higher than those given in either Berman (1988) or Holland and Powell (1990). Further compressibility experiments for talc are necessary to properly evaluate this adjustment, but the substitution of the $2.42 \mathrm{Mb}^{-1} \beta$ value results in a data base that can be used to generate accurate phase equilibria relations for the high pressure mineral reactions involving talc (Fig. 3). The $P-T$ shifts in these

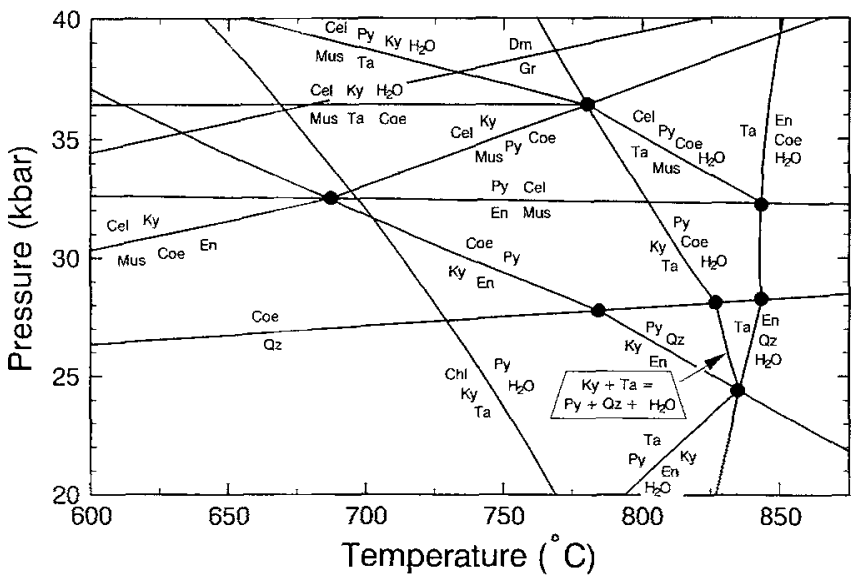

Fig. 3. Calculated phase diagram for selected reactions in the $\mathrm{MgO}-\mathrm{Al}_{2} \mathrm{O}_{3}-\mathrm{SiO}_{2}-\mathrm{H}_{2} \mathrm{O}$ system with the compressibility factor of $2.42 \mathrm{Mb}^{-1}$ for talc. Equilibria calculated for $a(\mathrm{Cel})=0.62$, $a(\mathrm{Mus})=0.38$ and $a(\mathrm{En})=1.0$. Graphite-diamond transition also shown (Kennedy and Kennedy, 1976). Abbreviations given in Fig. 2.

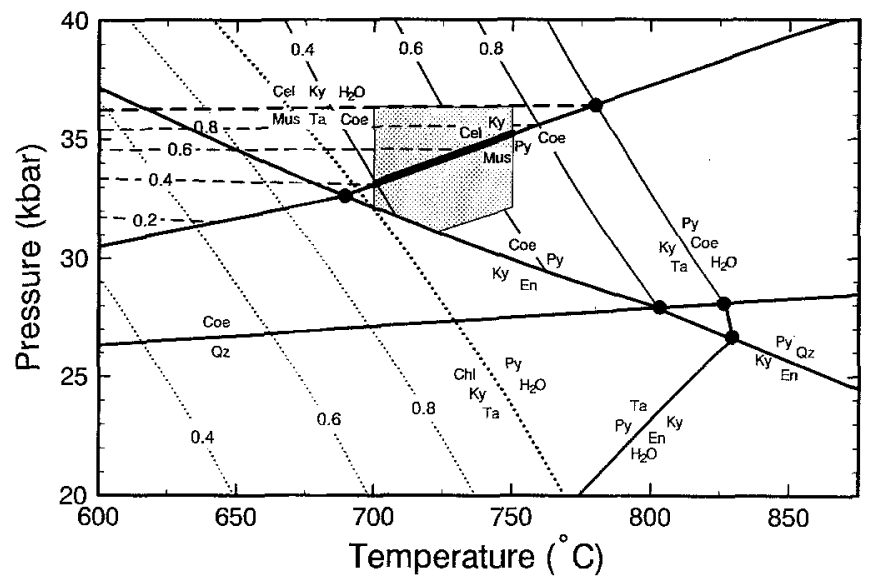

Fig. 4. Selected phase equilibria with contours for reduced water activity. Peak $P-T-a\left(H_{2} \mathrm{O}\right)$ estimates for the coesite-bearing whiteschists are delineated by the shaded polygon. Temperatures are limited by oxygen isotope thermometry. The peak $P-T$ must lie on the water-absent reaction 12 (shown as broad line between $\left.700-750^{\circ} \mathrm{C}\right)$. Minimum pressure are constrained by reaction 4 . The $a(\mathrm{En})$ corrected for MgTs component, $a(\mathrm{Cel})=0.62, a(\mathrm{Mus})=0.38$. Abbreviations given in Fig. 2.

curves can then be evaluated as a function of $a\left(\mathrm{H}_{2} \mathrm{O}\right)$ (Fig. 4).

The pressures of metamorphism are constrained by several reactions. The presence of coesite + pyrope and the absence of Al-enstatite requires minimum pressures of $28 \mathrm{~kb}$ at $800^{\circ} \mathrm{C}$ (reaction 4). This pressure constraint is significantly higher than coesite alone and is independent of the $\mathrm{H}_{2} \mathrm{O}$ activity. A second pressure-constraining reaction is based on the Si-content in phengite coexisting with talc, kyanite and coesite (Massonne and Schreyer 1989). The Si-content in phengite is buffered by the reaction

$$
\begin{array}{lcr}
3 \mathrm{KMgAlSi}_{4} \mathrm{O}_{10}(\mathrm{OH})_{2} & +3 \mathrm{Al}_{2} \mathrm{SiO}_{5} & +\mathrm{H}_{2} \mathrm{O}= \\
\text { celadonite } & \text { kyanite } & \\
3 \mathrm{KAl}_{3} \mathrm{Si}_{3} \mathrm{O}_{10}(\mathrm{OH})_{2} & +\mathrm{Mg}_{3} \mathrm{Si}_{4} \mathrm{O}_{10}(\mathrm{OH})_{2} & +2 \mathrm{SiO}_{2} \\
\text { muscovite } & \text { talc } & \text { coesite }
\end{array}
$$


Phengites from the Dora Maira coesite-bearing unit have $3.55 \mathrm{Si}$ per 12 oxygen (Chopin 1984). The experimental $P-T$ location of the $\mathrm{Si}_{3.55}$ isopleth (Massonne and Schreyer 1989) can be fit with the thermodynamic data set of Holland and Powell (1990) if the assumed activities of celadonite and muscovite are 0.62 and 0.38 , respectively. This is in fair agreement with the activities of celadonite and muscovite assuming an ideal molecular mixing model ( 0.55 and 0.45 respectively). By assuming activities of 0.62 and 0.38 for celadonite and muscovite, respectively, the $P-T$ shift for reaction (9) can be calculated as a function of $a\left(\mathrm{H}_{2} \mathrm{O}\right)$ (Fig. 4).

There are three other reactions that emanate from the invariant point defined by the intersection of reactions (1) and (9) (Fig. 3). These are the following:

$$
\begin{aligned}
& 3 \mathrm{KMgAlSi}_{4} \mathrm{O}_{10}(\mathrm{OH})_{2}+2 \mathrm{Al}_{2} \mathrm{SiO}_{5}+\mathrm{Mg}_{3} \mathrm{Al}_{2} \mathrm{Si}_{3} \mathrm{O}_{12}+2 \mathrm{H}_{2} \mathrm{O}= \\
& \text { celadonite kyanite pyrope } \\
& 3 \mathrm{KAl}_{3} \mathrm{Si}_{3} \mathrm{O}_{10}(\mathrm{OH})_{2}+2 \mathrm{Mg}_{3} \mathrm{Si}_{4} \mathrm{O}_{10}(\mathrm{OH})_{2} \\
& \text { muscovite talc } \\
& 3 \mathrm{KMgAlSi}_{4} \mathrm{O}_{10}(\mathrm{OH})_{2}+3 \mathrm{Mg}_{3} \mathrm{Al}_{2} \mathrm{Si}_{3} \mathrm{O}_{12}+4 \mathrm{SiO}_{2}+4 \mathrm{H}_{2} \mathrm{O}= \\
& \text { celadonite kyanite coesite } \\
& 3 \mathrm{KAl}_{3} \mathrm{Si}_{3} \mathrm{O}_{10}(\mathrm{OH})_{2}+4 \mathrm{Mg}_{3} \mathrm{Si}_{4} \mathrm{O}_{10}(\mathrm{OH})_{2} \\
& \text { muscovite talc } \\
& 3 \mathrm{KMgAlSi}_{4} \mathrm{O}_{10}(\mathrm{OH})_{2}+4 \mathrm{Al}_{2} \mathrm{SiO}_{5}= \\
& \text { celadonite kyanite } \\
& 3 \mathrm{KAl}_{3} \mathrm{Si}_{3} \mathrm{O}_{10}(\mathrm{OH})_{2}+\mathrm{Mg}_{3} \mathrm{Al}_{2} \mathrm{Si}_{3} \mathrm{O}_{12}+4 \mathrm{SiO}_{2} \\
& \text { muscovite pyrope coesite }
\end{aligned}
$$

The invariant point defined by reactions (1), (9), (10) and (11) will move along the water-absent reaction (12) to lower $P-T$ with decreasing $a\left(\mathrm{H}_{2} \mathrm{O}\right)$. In theory, the $P-T$ conditions of the coesite-bearing rock must lie on reaction (12), the actual $P-T$ depending upon the $\mathrm{H}_{2} \mathrm{O}$ activity. This $P-T-a\left(\mathrm{H}_{2} \mathrm{O}\right)$ field is illustrated in Fig. 4. Unfortunately, the P-T location of reaction (12) is not well known. It is based on the invariant point defined by reactions (1) and (9). The stability field of reaction (1) has been determined experimentally (Chopin 1985), but reaction (9) is based on unreversed experiments and incompletely characterized run products (Essene 1989). Ideally, the $P-T$ conditions of metamorphism must lie on reaction (12) within the temperature constraints defined by the oxygen isotope thermometric constraints (thick solid line segment in Fig. 4). A more conservative $P-T$ estimate for the peak metamorphic conditions is illustrated by the shaded polygon in Fig. 4. It is based on a $\pm 2 \mathrm{~kb}$ uncertainty for reaction 12 coupled with the constraints that pressures must lie above the well-calibrated, anhydrous reaction (4) and below the experimentally determined reaction (9).

Reaction (1) is the most temperature sensitive reaction applicable to the coesite-bearing whiteschists at Dora Maira and can be used in conjunction with the independent isotopic temperature estimates to constraint the $a\left(\mathrm{H}_{2} \mathrm{O}\right)$. Reaction (1) is located at $800^{\circ} \mathrm{C}$ at $30 \mathrm{~kb}$, well above the $700-750^{\circ} \mathrm{C}$ temperature estimates from oxygen isotope thermometry. The univariant assemblage defined by reaction (1) will be stable at $700-750^{\circ} \mathrm{C}, 30-35 \mathrm{~kb}$ at $a\left(\mathrm{H}_{2} \mathrm{O}\right)=0.4-0.7$ (Fig. 4). The best estimate of the peak metamorphic conditions for the coesite-bearing white- schist are $T=700-750^{\circ} \mathrm{C}, \quad P=32-36 \mathrm{~kb}, \quad a\left(\mathrm{H}_{2} \mathrm{O}\right)$ $=0.4-0.75$. The $P-T$ estimates are within a few $\mathrm{kb}$ of the stability field of diamond (Fig. 3), although no carbon phase has yet been identified in the Dora Maira whiteschists. Graphite has been found in neighbouring eclogite and marble units, but no diamond has yet been identified (Chopin personal communication 1992).

\section{Fluid and melt composition}

In order to maintain a reduced $\mathrm{H}_{2} \mathrm{O}$ activity and still produce pyrope + coesite from the dehydration reaction (1), a fluid diluent, such as $\mathrm{CO}_{2}$ or a melt, must have been present during metamorphism. A likely fluid diluent is $\mathrm{CO}_{2}$, as low $a\left(\mathrm{H}_{2} \mathrm{O}\right)$ is commonly attributed to $\mathrm{CO}_{2}$ streaming in granulite-facies terranes (e.g. Touret 1971; Janardhan et al. 1979). An examination of the stability of talc and kyanite in a mixed $\mathrm{CO}_{2}-\mathrm{H}_{2} \mathrm{O}$ fluid demonstrates that $\mathrm{CO}_{2}$ cannot, in fact, be the fluid diluent (Fig. 5). At $X\left(\mathrm{CO}_{2}\right)>0.02\left(T=750^{\circ} \mathrm{C}\right)$, pyrope is not stable. Magnesite is produced by the reaction

$$
\begin{aligned}
& 2 \mathrm{Mg}_{3} \mathrm{Al}_{2} \mathrm{Si}_{3} \mathrm{O}_{12}+3 \mathrm{CO}_{2}+\mathrm{H}_{2} \mathrm{O}= \\
& \text { pyrope } \\
& 3 \mathrm{MgCO}_{3}+2 \mathrm{Al}_{2} \mathrm{SiO}_{5}+\mathrm{Mg}_{3} \mathrm{Si}_{4} \mathrm{O}_{10}(\mathrm{OH})_{2} \\
& \text { magnesite kyanite } \quad \text { talc. }
\end{aligned}
$$

In the absence of an unusual fluid species (e.g. $\left.\mathrm{CH}_{4}, \mathrm{~N}_{2}\right)$, the low $a\left(\mathrm{H}_{2} \mathrm{O}\right)$ could only have been maintained by the presence of a melt. A melt would provide a sink for fluids evolved by the dehydration of talc. Reaction (1) could proceed with $P($ fluid $)<P($ total $)$ and $a\left(\mathrm{H}_{2} \mathrm{O}\right)<1$ (e.g. Valley et al. 1990). Experimental determination of the high pressure solidus have been made for natural granites (Boettcher and Wyllie 1968; Stern et al. 1975) and for bulk compositions in the system $\mathrm{NaAlSi}_{3}$ $\mathrm{KAlSi}_{3} \mathrm{O}_{8}-\mathrm{SiO}_{2}-\mathrm{H}_{2} \mathrm{O}$ (Huang and Wyllie 1975). The solidus determinations of Stern et al. (1975) for coesite-

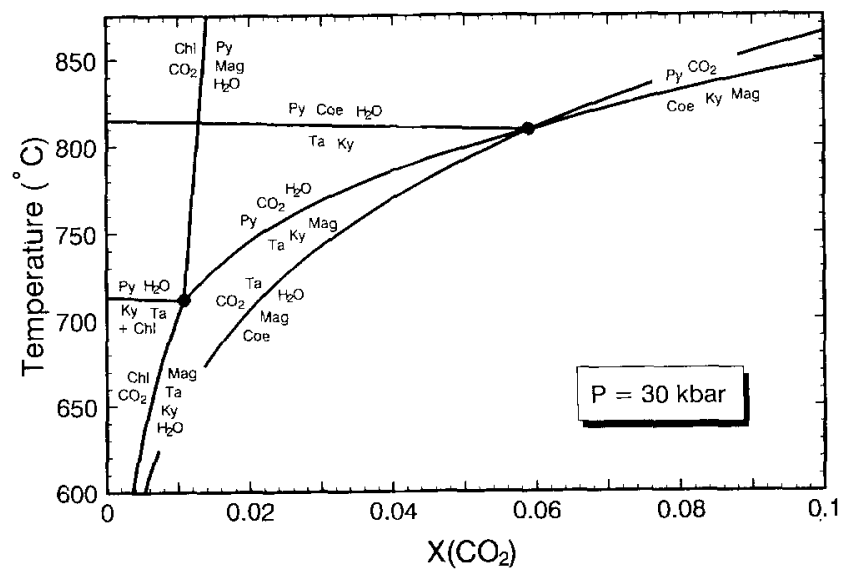

Fig. 5. Temperature- $X\left(\mathrm{CO}_{2}\right)$ phase diagram at $30 \mathrm{~kb}$, assuming $P($ fluid $)=P($ tot $)$ for selected phases in the $\mathrm{MgO}-\mathrm{Al}_{2} \mathrm{O}_{3}-\mathrm{SiO}_{2}-\mathrm{H}_{2} \mathrm{O}$ $\mathrm{CO}_{2}$ system. The stability field of pyrope and chlorite are limited to very low $X\left(\mathrm{CO}_{2}\right)$, indicating that the $X\left(\mathrm{CO}_{2}\right)$ must have been extremely low during prograde and retrograde conditions. Abbreviations given in Fig. 2 
jadeite-kyanite- $\mathrm{H}_{2} \mathrm{O}$ are identical to the results of Huang and Wyllie (1975) for jadeite-coesite- $\mathrm{KAlSi}_{3} \mathrm{O}_{8} \cdot \mathrm{H}_{2} \mathrm{O}$ $\mathrm{H}_{2} \mathrm{O}$ ), while the data of Boettcher and Wyllie give solidus temperatures that are $30^{\circ} \mathrm{C}$ higher. The solidus curve for $a\left(\mathrm{H}_{2} \mathrm{O}\right)=1.0$ is $\sim 680^{\circ} \mathrm{C}$ and $30 \mathrm{~kb}$ and $\sim 700^{\circ} \mathrm{C}$ at $35 \mathrm{~kb}$ (Fig. 6).

The granitic solidus will be displaced to higher temperatures with decreasing $a\left(\mathrm{H}_{2} \mathrm{O}\right)$. There are no reliable relationships between the wt. $\% \mathrm{H}_{2} \mathrm{O}$ versus $a\left(\mathrm{H}_{2} \mathrm{O}\right)$ for granitic melts at pressures $>20 \mathrm{~kb}$, but a crude estimate for the effect of $a\left(\mathrm{H}_{2} \mathrm{O}\right)$ on the high pressure solidus was made based on the relationship between wt. $\% \mathrm{H}_{2} \mathrm{O}$ versus $a\left(\mathrm{H}_{2} \mathrm{O}\right)$ for the $\mathrm{NaAlSi}_{3} \mathrm{O}_{8}-\mathrm{H}_{2} \mathrm{O}$ system between 0 and $10 \mathrm{~kb}$ (Eqs. 16-4; Burnham 1979). Applying Burnham's equation to granite melts at $30 \mathrm{~kb}$, the expected temperature shifts in the liquidus for $a\left(\mathrm{H}_{2} \mathrm{O}\right)=0.7$ and 0.5 are $\sim 70$ and $\sim 120^{\circ} \mathrm{C}$, respectively, based on the estimates of water-undersaturated liquidus surfaces for rhyolite (Stern et al. 1975). The solidus will also be shifted by $70-120^{\circ} \mathrm{C}$ for $a\left(\mathrm{H}_{2} \mathrm{O}\right)=0.5-0.7$, if the solidus- $a\left(\mathrm{H}_{2} \mathrm{O}\right)$ relations are similar to those for the liquidus. These estimates are not without large uncertainties, but they support our proposal that a melt phase was present during metamorphism.

Evidence for partial melting is preserved as the kyanite-jadeite-almandine quartz layers in the coesitebearing units. These layers have a much higher $\mathrm{Fe}$ and $\mathrm{Na}$ content than the surrounding coesite-bearing units, and approximate the eutectic composition for granite melts at high pressures. A partial melt origin for these layers has been proposed (Schreyer et al. 1987), although a source of the water for melting was not indicated. The $\mathrm{H}_{2} \mathrm{O}$ required for the melting of these units would be derived locally by the dehydration reaction (1). During cooling, the melts would crystallize and expel water back to the system. This water may be manifest in the occasionally observed altered pyrope megacrysts by reaction (6). Retrograde fluids could not have been pervasive, or all of the pyrope would have been hydrated. The stable isotope data support a local origin for the retrograde fluid. The $\delta^{18} \mathrm{O}$

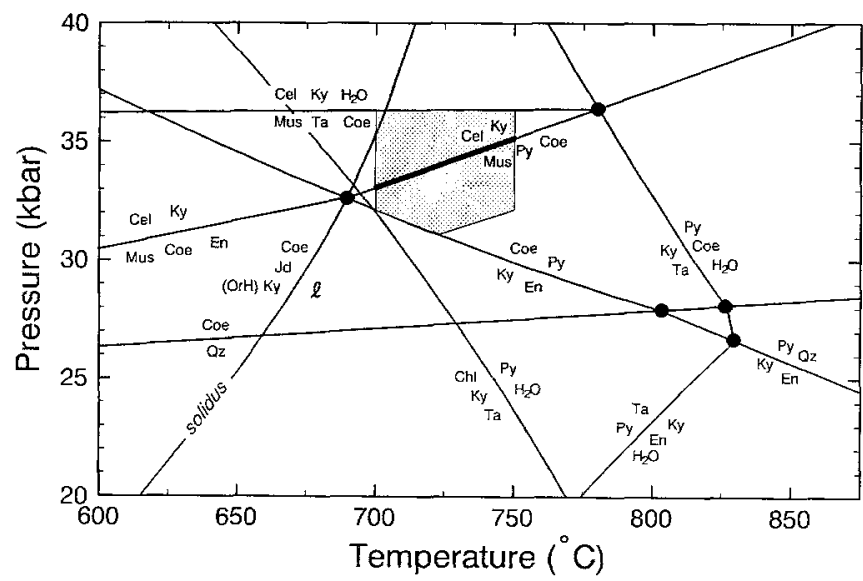

Fig. 6. Phase diagram with $P-T-a\left(\mathrm{H}_{2} \mathrm{O}\right)$ estimate (shaded polygon) and the water-saturated solidus for $\mathrm{Coe}+\mathrm{Jd}+\mathrm{Ky}$ (Stern et al. 1975) and Coe + Jd + OrH (Huang and Wyllie 1975). These two melting curves are identical within error. The $a(\mathrm{En})$ corrected for $\mathrm{MgTs}$ component, $a(\mathrm{Cel})=0.62, a(\mathrm{Mus})=0.38$. Abbreviations given in Fig. 2 values of the altered pyrope (AP-1) are only $1 \%$ lighter than the non-hydrated pyropes. In contrast, the surrounding orthogneiss is enriched in ${ }^{18} \mathrm{O}$ relative to the coesitebearing rocks by $3 \%$. If the fluids responsible for pyrope retrograde hydration had been from the surrounding orthogneisses, then the $\delta^{18} \mathrm{O}$ values for the altered samples would be higher, not lower, than those of the unaltered pyrope.

The presence of prograde and retrograde chlorite constrains the prograde and retrograde $a\left(\mathrm{CO}_{2}\right)$ to very low values. The stability field of chlorite at high pressure is restricted to extremely low $X\left(\mathrm{CO}_{2}\right)$ (Fig. 5). If the $X\left(\mathrm{CO}_{2}\right)$ was greater than 0.01 (at $30 \mathrm{~kb}$ ) or 0.04 (at $20 \mathrm{~kb}$, $<700^{\circ} \mathrm{C}$ ), chlorite would break down by the reaction

$$
\begin{aligned}
& 2 \mathrm{Mg}_{5} \mathrm{Al}_{2} \mathrm{Si}_{3} \mathrm{O}_{10}(\mathrm{OH})_{8}+7 \mathrm{CO}_{2}= \\
& \quad \text { chlorite } \\
& 7 \mathrm{MgCO}_{3}+2 \mathrm{Al}_{2} \mathrm{SiO}_{5}+\mathrm{Mg}_{3} \mathrm{Si}_{4} \mathrm{O}_{10}(\mathrm{OH})_{2}+7 \mathrm{H}_{2} \mathrm{O}
\end{aligned}
$$

magnesite kyanite talc

or, at higher temperatures,

$$
\begin{aligned}
& \mathrm{Mg}_{5} \mathrm{Al}_{2} \mathrm{Si}_{3} \mathrm{O}_{10}(\mathrm{OH})_{8}+2 \mathrm{CO}_{2}= \\
& \text { chlorite } \\
& 2 \mathrm{MgCO}_{3}+\mathrm{Mg}_{3} \mathrm{Al}_{2} \mathrm{Si}_{3} \mathrm{O}_{12}+4 \mathrm{H}_{2} \mathrm{O} \\
& \text { magnesite pyrope. }
\end{aligned}
$$

As chlorite is found as both prograde inclusions in garnet and retrograde products of pyrope hydration, it is clear that $\mathrm{CO}_{2}$ was never an important fluid component.

\section{Rock protolith and fuid origin}

The coesite-bearing quartzites are assumed to be higher grade equivalents of whiteschists (Schreyer 1977; Chopin 1984). Whiteschists consist almost exclusively of components in the $\mathrm{MgO}-\mathrm{Al}_{2} \mathrm{O}_{3}-\mathrm{SiO}_{2}-\mathrm{H}_{2} \mathrm{O}$ system with very low $\mathrm{Ca}, \mathrm{Na}$ and concentrations and a very low $\mathrm{Fe} / \mathrm{Mg}$ ratio. Several protoliths have been proposed for this unusual bulk chemistry. McKie (1959) suggested three possibilities: (1) a tectonic mixture of quartz with an ultrabasic rock, (2) magnesium metasomatism of an argillaceous sandstone, and (3) isochemical metamorphism of a saponitic bentonite. The first two scenarios do not adequately explain the $\mathrm{Ca}$ and $\mathrm{Al}$ contents of the whiteschists. The third possibility could involve weathering and/or leaching of basic pyroclastic rocks. Other authors have proposed hydrothermal alteration of basic to ultrabasic rocks or sedimentary rocks as the mechanism for whiteschist formation (Vallance 1967; Vrána 1975; Munz 1990; Hoernes and Van Reenen 1992). Schreyer (1977) argued that some of the whiteschists may be high-grade equivalents of metamorphosed mudstones associated with evaporites.

Stable isotope data from whiteschists can be used to limit the possible origin for these rocks. The $\delta^{18} \mathrm{O}_{\text {(quarz) }}$ values of the coesite-bearing whiteschists from Dora Maira $\left(\delta^{18} \mathrm{O}=8.1-8.7 \%\right)$ are in the normal range for charnockites/anorthosites and amphibolites/metabasites (Fig. 7). They are at the ${ }^{18} \mathrm{O}$-depleted end of metamorphic granitic rocks and orthogneisses and at the extreme lower limit for metapelites (Fig. 7). Other rock types, such as 


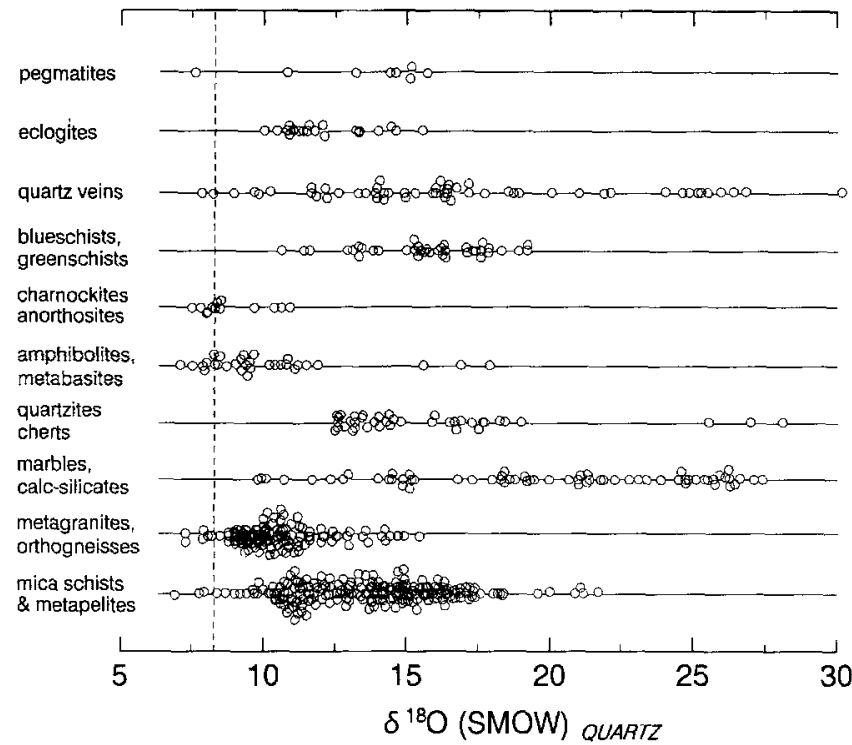

Fig. 7. Published $\delta^{18} \mathrm{O}_{\text {(quartz) }}$ values for metamorphic rocks and average value for the Dora Maira samples (vertical dashed line) Sources of data: Taylor and Epstein 1962; Taylor et al. 1963; Garlick and Epstein 1967; Taylor and Coleman 1968; Wilson et al. 1970; Schwarcz et al. 1970; Wilson and Green 1971; Perry and Tan 1972; Fourcade and Javoy 1973; Black 1974; Hoernes and Friedrichsen 1974, 1978, 1980; Honma and Sakai 1975; O'Neil and Ghent 1975; Frey et al. 1976; Margaritz and Taylor 1976; Rye et al. 1976 Desmons and O'Neil 1978; Rumble 1978; Friedrichsen and Morteani 1979; Hoernes and Hoffer 1979; McNaughton and Wilson 1980; Pineau et al. 1981; Brown and O'Neil 1982; Matthews and Schliestedt 1984; Valley and O'Neil 1984; Whelan et al. 1984; Robert et al. 1985; Thomas et al. 1985; Wickham and Taylor 1985; Huebner et al. 1986; Jiang et al. 1988; Sharp et al. 1988; Burkhard and Kerrich 1988; Baker 1990; Hoffbauer et al. 1992; Vennemann and Smith 1992

pegmatites, eclogites, blueschists and greenschists, quartzites, quartz veins, marbles and calc-silicates have $\delta^{18} \mathrm{O}$ values that are significantly higher than those of the Dora Maira whiteschists. Sediments, particularly those of authigenic origin, have a much higher $\delta^{18} \mathrm{O}$ value than the whiteschists from Dora Maira (e.g. Savin and Epstein 1970; O'Neil and Hay 1973; Savin 1980). The $\delta^{18}$ O values of the coesite-bearing unit are not matched by a mudstone or saponitic protolith. Normal prograde metamorphic effects do not lower the $\delta^{18} \mathrm{O}$ value of a rock by more than 1-2\% (e.g. Schwarcz et al. 1970; Desmons and O'Neil 1978; Valley 1986); if the whiteschist is of sedimentary origin, it must have undergone massive exchange with an isotopically light fluid. If the system remained essentially closed, then the observed $\delta^{18} \mathrm{O}$ values are far better matched by a hydrothermally altered or metasomatized igneous rock protolith. In contrast to the whiteschist, the surrounding orthogneiss has a typical granite isotopic signature, and is clearly not in equilibrium with the whiteschist boudins it hosts.

The $\delta \mathrm{D}$ values of the talc $(\delta \mathrm{D}=-32 \%)$ and phengite $(\delta \mathrm{D}=-35 \%)$ in the coesite-bearing unit are at the extreme upper limit for metamorphic rocks (Fig. 8; Taylor 1974). The surrounding orthogneisses have similar $\delta \mathrm{D}_{\text {(phengite) }}$ values as do the hydrated pyrope megacrysts

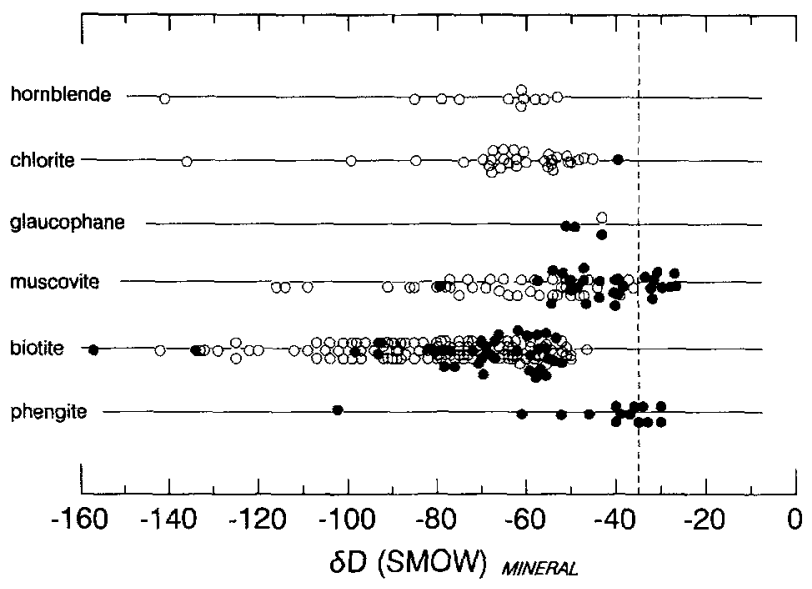

Fig. 8. Published $\delta \mathrm{D}$ values of in metamorphic rocks and $\delta \mathrm{D}_{\text {(phengite) }}$ value from this study (vertical dashed line). The filled circles are Alphine samples. Sources of data: O'Neil and Ghent 1975; Frey et al. 1976; Margaritz and Taylor 1976; Rye et al. 1976; Desmons and O'Neil 1978; Friedrichsen and Morteani 1979; Hoernes and Hoffer 1979; Hoernes and Friedrichsen 1978, 1980; Pineau et al. 1981; Thomas et al. 1985; Morikiyo 1986; Huebner et al. 1986; Wickham and Taylor 1985; McCaig et al. 1990

(Table 1). The $\delta D_{\text {(biotite) }}$ value of $-64 \%_{0}$ in the orthogneiss are in isotopic equilibrium with the coexisting phengite (Suzuoki and Epstein 1976). Other rocks that have equivalent $\delta \mathrm{D}$ values are (1) Alpine rocks that have undergone ecologitization at some point in their metamorphic history (Frey et al. 1976; Desmons and O'Neil 1978; G. Früh-Green personal communication), (2) rocks that have experienced extensive hydrothermal seawater interaction (Wickham and Taylor 1985) and (3) altered/metamorphic sea-floor basalts (Kawahata et al. 1987; Kusakabe et al. 1989; Stakes 1991). The proposed source of the high $\delta \mathrm{D}$ values from Alpine samples in previous studies is connate waters, presumably of oceanic affinity (Frey et al. 1976). The $\delta \mathrm{D}$ values for the Dora Maira rocks are, therefore, indicative of an oceanic source, but do not constrain the time at which the fluid-rock interaction took place. The fluids could be connate or introduced at a later point in their metamorphic history from dewatering of underlying altered oceanic rocks in a downgoing slab.

The similarity of the $\delta \mathrm{D}$ values from the coesite-bearing and surrounding units demonstrates large-scale hydrogen isotope equilibrium during metamorphism. In contrast, the $\delta^{18} \mathrm{O}$ values of the coesite-bearing rocks and the surrounding orthogneisses are out of equilibrium, although oxygen isotope equilibrium was attained in all samples of the whiteschist. Large-scale hydrogen isotope equilibrium has previously been observed in the Alps (Frey et al. 1976; Desmons and O'Neil 1978), and is not unexpected. First, the rates of exchange for hydrogen are far more rapid than for oxygen ( $O$ 'Neil and Kharaka 1976; Graham 1981), and second, hydrogen tends to be buffered by a fluid phase, whereas oxygen is rock buffered. The mutually high $\delta \mathrm{D}$ values in both units indicate that both shared a common fluid source at some point in their metamorphic history. The whiteschist has attained inter- 
nal oxygen isotope equilibrium on a 10 to $100 \mathrm{~m}$ scale, but not with the surrounding orthogneiss. The mechanism responsible for oxygen isotope homogenization in the whiteschist was not shared with the present-day host rock.

The combined oxygen and hydrogen isotope geochemistry for the Dora Maira whiteschists are very unusual. The isotopically light $\delta^{18} \mathrm{O}$ and heavy $\delta \mathrm{D}$ values are similar to high-temperature sea floor metamorphosed basalts (Kawahata et al. 1987; Kusakabe et al. 1989; Stakes 1991), but different from almost all other rock types. Metamorphosed oceanic rocks could either be the protolith for the Dora Maira whiteschists, or could have supplied the fluids responsible for the generation of the whiteschists. In the first case, the basalts would be subducted to depths in excess of $100 \mathrm{~km}$ and undergo metasomatism without extensively altering their stable isotope composition. In the second case, the dehydration of a metamorphosed, hydrated oceanic crust in the downgoing slab would provide a fluid source for metasomatism of an overlying layer. The intercalation of the orthogneiss with the whiteschist has recently been reinterpreted as a pre- or early Alpine hydrothermal metasomatic transformation of the hosting orthogneiss/granite along shear zones (Chopin et al. 1991). Dehydrating metabasalts could be the fluid source for this metasomatism.

Dehydration of a downgoing slab begins at shallow levels, but will continue to depths in excess of $100 \mathrm{~km}(\mathrm{e} . \mathrm{g}$. Tatsumi 1989; Kesson and Ringwood 1989). Fluids evolved from the breakdown of hydrous phases could cause melting of an overlying, hot eclogite, with an initial partial melt that is up to $60-65 \% \mathrm{SiO}_{2}$ (Kesson and Ringwood 1989). The fluid generated from phlogopite dehydration experiments (Massonne and Schreyer 1986) is highly enriched in potassium and magnesium (Schreyer et al. 1987). Metasomatism of the orthogneisses along shear zones by such $\mathrm{K}-\mathrm{Mg}$-Si-rich fluids/partial melts would partly explain the unusual chemistry of the whiteschists. The very low $\mathrm{Fe} / \mathrm{Mg}$ ratio may be explained by metasomatism in an oxidizing environment. The different geochemical behaviour of $\mathrm{Fe}^{+++}$and $\mathrm{Mg}$ would explain the strong $\mathrm{Mg}-\mathrm{Fe}$ partitioning accompanying metasomatism. There are no $f\left(\mathrm{O}_{2}\right)$ buffers in the Dora Maira whiteschists, but other whiteschists contain hematite-rich layers indicative of high $f\left(\mathrm{O}_{2}\right)$ conditions (McKie 1959; Vrána and Barr 1972; Munz 1990) that could explain the preferential metasomatic depletion of iron. Metasomatism of the orthogneiss protolith by a slab-derived fluid can therefore explain (1) the unusual hydrogen and oxygen isotope composition of the whiteschists, (2) the enigmatic and intimate structural relationship between the whiteschists and the hosting orthogneiss, (3) the depletion in the Fe-content of the rock and (4) the enrichment of $\mathrm{Mg}$ in the whiteschists. Further experimental studies that reproduce the metasomatic activity proposed here are necessary to substantiate or discredit this hypothesis of whiteschist formation.

Acknowledgements. The authors would like to thank C. Chopin for kindly providing experimental results and ideas, G.F. Green for unpublished stable isotope data, G. Martinotti for field guidance and P. Ulmer and J.A.D. Connolly for informative discussions throughout the course of this work. C. Chopin, M.A. Cosca, S. Hoernes and G.R. Tilton are thanked for their very helpful and perceptive reviews. The editorial handling of $\mathrm{V}$. Trommsdorff is appreciated. This work was supported by Swiss National Science Foundation grants to JCH and ZDS and US NSF grant number EAR 90-07072 to EJE.

\section{References}

Agrinier P (1991) The natural calibration of ${ }^{18} \mathrm{O} /{ }^{16} \mathrm{O}$ geothermometers : application to the quartz-rutile mineral pair. Chem Geol $91: 49-64$

Baker AJ (1990) Stable isotopic evidence for fluid-rock interactions in the Ivrea Zone, Italy, J Petrol $31: 243-260$

Berman RG (1988) Internally-consistent thermodynamic data for minerals in the system $\mathrm{Na}_{2} \mathrm{O}-\mathrm{K}_{2} \mathrm{O}-\mathrm{Ca}-\mathrm{MgO}-\mathrm{FeO}-\mathrm{Fe}_{2} \mathrm{O}_{3}-$ $\mathrm{Al}_{2} \mathrm{O}_{3}-\mathrm{SiO}_{2}-\mathrm{TiO}_{2}-\mathrm{H}_{2} \mathrm{O}-\mathrm{CO}_{2}$. J Petrol $29: 445-522$

Black PM (1974) Oxygen isotope study of metamorphic rocks from the Ouégoa District, New Caledonia. Contrib Mineral Petrol 47: 197-206

Boettcher AL, Wyllie PJ (1968) Melting of granite with excess water to 30 kilobars pressures. J Geol $76: 235-244$

Bottinga $Y$, Javoy $M$ (1975) Oxygen isotope partitioning among the minerals in igneous and metamorphic rocks. Rev Geophys Space Phys 13:401-418

Brown EH, O'Neil JR (1982) Oxygen isotope geothermometry and stabilty of lawsonite and pumpellyite in the Shuksan Suite, North Cascades, Washington. Contrib Mineral Petrol 80:240-244

Burkhard M, Kerrich R (1988) Fluid regimes in the deformation of the Helvetic nappes, Switzerland, as inferred from stable isotope data. Contrib Mineral Petrol 99:416-429

Burnham CW (1979) The importance of volatile constituents. In: Yoder HS Jr (ed) The evolution of the igneous rocks: Fiftieth Anniversry perspectives. Princeton University Press, Princeton, pp. $902-940$

Chesnokov BV, Popov VA (1965) Increase in the volume of quartz grains in South Urals eclogite. Dokl Akad Nauk SSSR 162:176-178

Chopin C (1984) Coesite and pure pyrope in high-grade blueschists of the Western Alps: a first record and some consequences. Contrib Mineral Petrol 86:107-118

Chopin C (1985) Les relations de phases dans les métapelites de haute pression: approaches expérimentale et naturaliste, conséquences géodynamiques pour les Alpes occidentales. Thèse d'état, Université de Paris 6, Paris

Chopin C (1986) Phase relationships of ellenbergerite, a new highpressure $\mathrm{Mg}$-Al-Ti-silicate in pyrope-coesite-quartzite from the Western Alps. Geol Soc Am Mem 164:31-42

Chopin C (1987) Very-high-pressure metamorphism in the western Alps: implications for subduction of continental crust. Philos Trans R Soc London A 321:183-197

Chopin C, Henry C, Michard A (1991) Geology and petrology of the coesite-bearing terrain, Dora Maira massif, Western Alps. Eur J Mineral 3:263-291

Desmons J, O'Neil JR (1978) Oxygen and hydrogen isotope compositions of eclogites and associated rocks from the Eastern Sesia Zone (Western Alps, Italy). Contrib Mineral Petrol 67:79-85.

Enami M, Zang Q (1990) Quartz pseudomorphs after coesite in eclogites from Shandong Province, east China. Am Mineral $75: 381-386$

Essene EJ (1989) The current status of thermobarometry in metamorphic rocks. In: Daly JS, Cliff RA, Yardley BWD (eds) Evolution of metamorphic rocks. Geol Soc Spec Publ 43:1-44

Farver JR, Yund RA (1991) Oxygen diffusion in quartz: dependence on temperature and water fugacity. Chem Geol 90:55-70

Fourcade S, Javoy M (1973) Rapports ${ }^{18} \mathrm{O} /{ }^{16} \mathrm{O}$ dans les roches du vieux socle catazonal d'In Ouzzal (Sahara algérien). Contrib Mineral Petrol 42: 235-244

Frey M, Hunziker JC, O'Neil JR, Schwander HW (1976) Equilibrium-disequilibrium relations in the Monte Rosa granite, Western Alps: petrological, $\mathrm{Rb}-\mathrm{Sr}$ and stable isotope data. Contrib Mineral Petrol 55:147-179 
Friedrichsen H, Morteani G (1979) Oxygen and hydrogen isotope studied on minerals from Alpine fissures and their gneissic host rocks, western Tauern Window (Austria). Contrib Mineral Petrl $70: 149-152$

Garlick GD, Epstein S (1968) Oxygen isotope ratios in coexisting minerals of regionally metamorphosed rocks. Geochim Cosmochim Acta $31: 181-214$

Gasparik T, Newton RC (1984) The reversed alumina contents of orthopyroxene in equilibrium with spinel and forsterite in the system $\mathrm{MgO}-\mathrm{Al}_{2} \mathrm{O}_{3}-\mathrm{SiO}_{2}$. Contrib Mineral Petrol 85:186-196

Graham CM (1981) Experimental hydrogen isotope studies III: diffusion of hydrogen in hydrous minerals, and stable isotope exchange in metamorphic rocks. Contrib Mineral Petrol $76: 216-228$

Hirajima T, Ishiwatari A, Cong B, Zhang R, Bann S, Nozaka $T$ (1991) Coesite from Mengzhong eclogite at Donghai county, northeastern Jiangsu province, China. Mineral Mag 54 : 579-583

Hoernes S, Friedrichsen H (1974) Oxygen isotope studies on metamorphic rocks of the Western Hole Tauern Area (Austria). Schweiz Mineral Petrogr 54:769-788

Hoernes S, Friedrichsen H (1978) Oxygen and hydrogen isotope study of the polymetamorphic area of the northern Ötztal-Stubai Alps (Tyrol). Contrib Mineral Petrol 67: 305-315

Hoernes S, Friedrichsen H (1980) Oxygen and hydrogen isotopic composition of Alpine and Pre-Alpine minerals of the Swiss Central Alps. Contrib Mineral Petrol 72:19-32

Hoernes S, Hoffer E (1979) Equilibrium relations of prograde metamorphic mineral assemblages. A stable isotope study of rocks of the Damara Orogen, from Namibia. Contrib Mineral Petrol $68: 377-389$

Hoernes S, van Reenen DD (1992) The oxygen-isotopic composition of granulites and retrogressed granulites from the Limpopo Belt as a monitor of fluid-rock interaction. Precamb Res 55:353-364

Hoffbauer R, Hoernes S, Fiorentini E (1993) Oxygen isotope thermometry on granulite-grade rocks from Sri Lanka. Precamb Res (in press)

Holland TJB, Poweil R (1990) An enlarged and updated internally consistent thermodynamic dataset with uncertainties and correlations: the system $\mathrm{K}_{2} \mathrm{O}-\mathrm{Na}_{2} \mathrm{O}-\mathrm{CaO}-\mathrm{MgO}-\mathrm{MnO}-\mathrm{FeO}-\mathrm{Fe}_{2} \mathrm{O}_{3}-$ $\mathrm{Al}_{2} \mathrm{O}_{3}-\mathrm{TiO}_{2}-\mathrm{SiO}_{2}-\mathrm{C}-\mathrm{H}_{2}-\mathrm{O}_{2}$. J Metam Geol 8:89-124

Honma H, Sakai H (1975) Oxygen isotope study of metamorphic and granitic rocks of the Yanai District in the Ryoke Belt, Japan. Contrib Mineral Petrol 52:107-120

Huang WL, Wyllie PJ (1975) Melting reactions in the system $\mathrm{NaAlSi}_{3} \mathrm{O}_{8}-\mathrm{KAlSi}_{3} \mathrm{O}_{8}-\mathrm{SiO}_{2}$ to 35 kilobars, dry and with excess water. J Geol 83:737-748

Huebner M, Kyser TK, Nisbet EG (1986) Stable-isotope geochemistry of high-grade metapelites from the Central zone of the Limpopo belt. Am Mineral 71 : 1343-1353

Janardhan AS, Newton RC, Smith JV (1979) Ancient crustal metamorphism at low $p_{\mathrm{H}_{2} \mathrm{O}}$ : charnockite formation at Kabbaldurga, South India. Nature 278:511-514

Javoy M, Fourcade S, Allegre CJ (1970) Graphical method for examination of ${ }^{18} \mathrm{O} /{ }^{16} \mathrm{O}$ fractionations in silicate rocks. Earth Planet Sci Lett 10:12-16

Jiang J, Clayton RN, Newton RC (1988) Fluids in granulite facies metamorphism: a comparative oxygen isotope study on the South India and Adirondacks high-grade terrains. J Geol $96: 517-533$

Kawahata H, Kusakabe M, Kikuchi Y (1987) Strontium oxygen and hydrogen isotope geochemistry of hydrothermally altered and weathered rocks in DSDP Hole 504B, Costa Rica Rift. Earth Planet Sci Lett $85: 343-355$

Kennedy CS, Kennedy GC (1976) The equilibrium boundary between graphite and diamond. J Geophys Res $81: 2467-2470$

Kesson SE, Ringwood AE (1989) Slab-mantle interactions 1. Sheared and refertilised garnet peridotite xenoliths--samples of the Wadati-Benioff zones? Chem Geol 78:83-96

Kienast JR, Lombardo B, Biino G, Pinardon JL (1991) Petrology of very-high-pressure eclogite rocks from the Brossasco-Isasca complex, Dora-Maira Massif, Italian Western Alps. J Metam Geol 9:19-34
Kitahara S, Takenouchi S, Kennedy GC (1966) Phase relations in the system $\mathrm{MgO}-\mathrm{SiO}_{2}-\mathrm{H}_{2} \mathrm{O}$ at high temperatures and pressures. Am J Sci 264:223-233

Kusakabe M, Shibata T, Yamamoto M, Mayeda S, Kagami H, Honma $\mathrm{H}$, Masuda $\mathrm{H}$, Sakai $\mathrm{H}$ (1989) 5. Petrology and isotope characteristics $(\mathrm{H}, \mathrm{O}, \mathrm{S}, \mathrm{Sr}$, and $\mathrm{Nd})$ of basalts from ocean drilling program Hole 504B, Leg 111, Costa Rica Rift. In: Proceedings of the Ocean Drilling Program, scientific results $111: 47-60$

Lichtenstein U, Hoernes S (1992) Oxygen isotope fractionation between grossular-spessartine garnet and water: an experimental investigation. Eur J Mineral-4:239-249

Margaritz M, Taylor HP Jr (1976) Oxygen, hydrogen and carbon isotope studies of the Franciscan formation, Coast Ranges, California. Geochim Cosmochim Acta 40:215-234

Massonne H-J (1983) Experiments on melting to $50 \mathrm{kbar}$ in the system $\mathrm{MgO}-\mathrm{Al}_{2} \mathrm{O}_{3}-\mathrm{SiO}_{2}-\mathrm{H}_{2} \mathrm{O}(\mathrm{MASH})$ with excess $\mathrm{SiO}_{2}$ and $\mathrm{H}_{2} \mathrm{O}$. EOS $64: 875$

Massonne H-J, Schreyer W (1986) High-pressure syntheses and $\mathrm{X}$-ray properties of white micas in the system $\mathrm{K}_{2} \mathrm{O}-\mathrm{MgO}-\mathrm{Al}_{2} \mathrm{O}_{3}$ $\mathrm{SiO}_{2}-\mathrm{H}_{2} \mathrm{O}$. Neues Jahrb Mineral (Abh) 153:177-215

Massonne H-J, Schreyer W (1989) Stability field of the high-pressure assemblage talc + phengite and two new phengite barometers. Eur J Mineral 1:391-410

Matthews A (1992) Oxygen isotope geothermometers for high pressure metamorphic rocks. In: Stable isotopes as tracers of metamorphic processes. Abstr Prog Internat Geol Correlation Prog $304: 30$

Matthews A, Schliestedt M (1984) Evolution of the blueschist and greenschist facies rocks of Sifnos, Cyclades, Greece. A stable isotope study of subduction-related metamorphism. Contrib Mineral Petrol 88:150-163

McCaig AM, Wickham SM, Taylor HP Jr (1990) Deep Fluid circulation in alpine shear zones, Pyrenees France: field and oxygen isotope studies. Contrib Mineral Petrol 106:41-60

McKie D (1959) Yoderite, a new hydrous magnesium aluminosilicate from Mautia Hill, Tanganyika, Mineral Mag 32: 282-307

McNaughton NJ, Wilson AF (1980) Problems in oxygen isotope geothermometry in mafic granulite facies rocks from near Einasleigh, Northern Queensland. Prec Camb Res 13:77-86

Moniê $\mathrm{P}$, Chopin $\mathrm{C}(1991){ }^{40} \mathrm{Ar}-{ }^{39} \mathrm{Ar}$ dating in coesite-bearing and associated units of the Dora Maira massif, western Alps. Eur J Mineral 3:239-262

Morikiyo T (1986) Hydrogen and carbon isotope studies on the graphite-bearing metapelites in the northern Kiso district of central Japan. Contrib Mineral Petrol $94: 165-177$

Munz IA (1990) Whiteschists and orthoamphibole-cordierite rocks and the P-T-t path of the Modum Complex, South Nroway. Lithos 24: 181-200

Okay AI, Xu S, Sengor AMC (1989) Coesite from the Dabie Shan eclogites, central China. Eur J Mineral 1:595-598

O'Neil JR, Ghent ED (1975) Stable isotope study of coexiting metamorphic minerals from the Esplanade Range, British Columbia. Geol Soc Am Bull 86:1708-1712

O'Neil JR, Hay RL (1973) ${ }^{18} \mathrm{O} /{ }^{16} \mathrm{O}$ ratios in cherts associated with the saline lake deposits of East Africa. Earth Planet Sci Lett $19: 257-266$

O'Neil JR, Kharaka YK (1976) Hydrogen and oxygen isotope exchange reactions between clay minerals and water. Geochim Cosmochim Acta 40:241-246

Pacquette J-L, Chopin C, Peucat I-J (1989) U-Pb zircon, Rb-Sr and Sm-Nd geochronology of high to very-high-pressure meta-acidic rocks from the Western Alps. Contrib Mineral Petrol $101: 280-289$

Perkins D III, Holland TJB, Newton RC (1981) The $\mathrm{Al}_{2} \mathrm{O}_{3}$ contents of enstatite in equilibrium with garnet in the system $\mathrm{MgO}$ $\mathrm{Al}_{2} \mathrm{O}_{3}-\mathrm{SiO}_{2}$ at $15-40 \mathrm{kbar}$ and $900^{\circ}-1600^{\circ} \mathrm{C}$. Contrib Mineral Petrol 78:99-109

Perry EC Jr, Tan FC (1972) Significance of oxygen and carbon isotope variations in early Precambrian cherts and carbonate rocks of southern Africa. Geol Soc Am Bull 83:647-664 
Pineau F, Javoy M, Behar F, Touret J (1981) La géochimie isotopique du faciès granulite du Bamble (Norvège) et l'origine des fluides carbonés dans la croûte profonde. Bull Mineral $104: 630-641$

Powell R, Holland TJB (1988) An internally consistent thermodynamic dataset with uncertainties and correlations: 3 . Applications to geobarometry, worked examples and a computer program. J Metam Geol 6:173-204

Reinecke T (1991) Very-high-pressure metamorphism and uplift of coesite-bearing metasediments from the Zermatt-Saas zone, Western Alps. Eur J Mineral 3:7-17

Robert C, Javoy M, Kienast J-R (1985) Coefficients de distribution et mesures isotopiques ${ }^{18} \mathrm{O} /{ }^{16} \mathrm{O}$ comparisons thermométriques et barométriques sur quelques éclogites et micaschistes de la zone Sesia-Lanzo (Alpes italiennes). Bull Mineral 108:699-711

Rossman GR, Beran A, Langer K (1989) The hydrous component of pyrope from the Dora Maira Massif, Western Alps. Eur J Mincral $1: 151-154$

Rumble D III (1978) Mineralogy, petrology and oxygen isotope geochemistry of the Clough Formation, Black Mountain, Western New Hampshire, USA. J Petrol 19:317-340

Rye RO, Schuiling RD, Rye DM, Hansen JBH (1976) Carbon, hydrogen, and oxygen isotope studies of the regional metamorphic complex at Naxos, Greece. Geochim Cosmochim Acta 40:1031-1049

Savin SM (1980) Oxygen and hydrogen isotope effects in lowtemperature mineral-water interactions. In: Fritz AP, Fontes JCh (eds) The terrestrial environment. Handbook of environmental isotope geochemistry, vol. 1. Elsevier, Amsterdam, pp. 283-327

Savin SM, Epstein S (1970) The oxygen and hydrogen isotope geochemistry of clay minerals. Geochim Cosmochim Acta $34: 25-42$

Schertl H-P, Schreyer W, Chopin C (1991) The pyrope-coesite rocks and their country rocks at Parigi, Dora Maira Massif, Western Alps: detailed petrography, mineral chemistry and $P$ - $T$-path. Contrib Mineral Petrol 108:1-21

Schmädicke E (1991) Quartz pseudomorphs after coesite in eclogites from the Saxonian Erzgebirge. Eur J Mineral 3:231-238

Schreyer W (1977) Whiteschists: their compositions and pressuretemperature regimes based on experimental, field, and petrographic evidence. Tectonophysics $43: 127-144$

Schreyer W, Massonne H-J, Chopin C (1987) Continental crust subducted to depths near $100 \mathrm{~km}$ : implications for magma and fluid genesis in collision zones. In: Mysen BO (ed) Magmatic processes: physiochemical principles. Geochem Soc Spec Pub $1: 155-163$

Schwarcz HP, Clayton RN, Mayeda T (1970) Oxygen isotopic studies of calcareous and pelitic metamorphic rocks, New England. Geol Soc Am Bull 81:2299-2316

Sharp ZD (1990) A laser-based microanalytical method for the in situ determination of oxygen isotope ratios in silicates and oxides. Geochim Cosmochim Acta 54:1353-1357

Sharp ZD (1992) In situ laser microprobe techniques for stable isotope analysis. Chem Geol $101: 3-19$

Sharp ZD, O'Neil JR, Essene EJ (1988) Oxygen isotope variations in granulite-grade iron formations: constraints on oxygen diffusion and retrograde isotopic exchange. Contrib Mineral Petrol 98: 490-501

Sharp ZD, Giletti BJ, Yoder HS Jr (1991) Oxygen diffusion rates in quartz exchanged with $\mathrm{CO}_{2}$. Earth Planet Sci Lett 107: 339-348

Sharp ZD, Essene EJ, Smyth JR (1992) Uitra-high temperatures from oxygen isotope thermometry of a coesite-sanidine grospydite. Contrib Mineral Petrol 112:358-370

Shutong X, Okay AI, Shouyuan J, Sengör AMC, Wen S, Yican L, Laili J (1992) Diamond from the Dabie Shan metamorphic rocks and its implication for tectonic setting. Science $256: 80-82$

Smith DC (1984) Coesite in clinopyroxene in the Caledonides and its implications for geodynamics. Nature 310:641-644

Smith DC, Lappin MA (1987) Coesite in the Straumen kyaniteeclogite pod, Norway. Terra Res 1:47-56
Sobolev NV, Shatsky VS (1990) Diamond inclusions in garnets from metamorphic rocks: a new environment for diamond formation. Nature 343:742-745

Stakes DS (1991) Oxygen and hydrogen isotope compositions of oceanic plutonic rocks: High-temperature deformation and metamorphism of oceanic layer 3. In: Taylor HP JR, O'Neil JR, Kaplan IR (eds) Stable isotope geochemistry: a tribute to Samuel Epstein. The Geochemical Society Spec Pub 3: 77-90

Stern CR, Huang WL, Wyllie PJ (1975) Basalt-andesite-rhyolite$\mathrm{H}_{2} \mathrm{O}$ : crystallization intervals with excess $\mathrm{H}_{2} \mathrm{O}$ and $\mathrm{H}_{2} \mathrm{O}$-undersaturated liquidus surfaces to 35 kilobars, with implications for magma genesis. Earth Planet Sci Lett 28:189-196

Suzuoki T, Epstein S (1976) Hydrogen isotope fractionation between $\mathrm{OH}$-bearing minerals and water. Geochim Cosmochim Acta $40: 1229-1240$

Tagiri M, Bakirov A (1990) Quartz pseudomorph after coesite in garnet from a garnet-chloritoid-talc schist, northern Tien-Shan, Kirghiz, SSR. Proc Japan Acad 66:135-139

Tatsumi Y (1989) Migration of fluid phases and genesis of basalt magmas in subduction zones. J Geophys Res 94:4697-4707

Taylor HP Jr (1974) The application of oxygen and hydrogen isotope studies to problems of hydrothermal alteration and ore deposition. Econ Geol $69: 843-883$

Taylor HP Jr, Coleman RG (1968) $\mathrm{O}^{18} / \mathrm{O}^{16}$ ratios of coexisting minerals in glaucophane-bearing metamorphic rocks. Geol Soc Am Bull 79:1727-1756

Tayior HP Jr, Epstein S (1962) Relationship between $\mathrm{O}^{18} / \mathrm{O}^{16}$ ratios in coexisting minerals of igneous and metamorphic rocks. Geol Soc Am Bull 73:675-694

Taylor HP Jr, Albee AL, Epstein S (1963) $\mathrm{O}^{18} / \mathrm{O}^{16}$ ratios of coexisting minerals in three assemblages of kyanite-zone pelitic schist. J Geol $71: 513-522$

Thomas LJ, Harmon RS, Oliver GJH (1985) Stable isotope composition of alteration fluids in low-grade lower Palaeozoic rocks, English Lake District. Mineral Mag 49:425-434

Tilton GR, Schreyer W, Schertl H-P (1989) Pb-S $-\mathrm{Nd}$ isotopic behavior of deeply subducted crystal rocks from Dora Maira Massif, Western Alps, Italy. Geochim Cosmochim Acta $53: 1391-1400$

Tilton GR, Schreyer W, Schertl H-P (1991) Pb-Sr-Nd isotopic behavior of deeply subducted crystal rocks from the Dora Maira Massif, Western Alps, Italy-II: what is the age of the ultrahighpressure metamorphism? Contrib Mineral Petrol 108:22-33

Touret J (1971) Le facies granulite en Norvège méridionale. Lithos $4: 239-249$

Vaidya SN, Beiley S, Pasternack T, Kennedy GC (1973) Compressibility of fifteen minerals to 45 kilobars. J Geophys Res 78:6893-6898

Vallance TG (1967) Mafic rock alteration and isochemical development of some cordierite-anthophyllite rocks. J Petrol 8:84-96

Valley JW (1986) Stable isotope geochemistry of metamorphic rocks. In: Valley JW, Taylor HP JR, O'Neil JR (eds) Stable isotopes in high temperature geological processes. Rev Mineral $16: 445-489$

Valley JW, O'Neil JR (1984) Fluid heterogeneity during granulite facies metamorphism in the Adirondacks: stable isotope evidence, Contrib Mineral Petrol 85:158-173

Valley JW, Bohlen SR, Essene EJ, Lamb W (1990) Metamorphism in the Adirondacks II. The role of fluids. J Petrol 31:555-596

Vennemann TW, O'Neil JR (1993) A simple and inexpensive method of hydrogen isotope analysis of minerals and rocks based on zinc reagent. Isotope Geosci (in press)

Vennemann TW, Smith HS (1992) Stable isotope profile across the orthoamphibole isograd in the Southern Marginal Zone of the Limpopo Belt, South Africa. Precamb Res 55:365-397

Vialon P (1966) Etude géologique du massif cristallin Dora-Maira, Alpes cottiennes internes, Italie. Thèse d'état, Université de Grenoble

Vrána S (1975) Magnesian-aluminous rocks, the associated ore mineralization and the problem of magnesium-iron metasomatism. Krystallinikum 11:101-114

Vrána S, Barr MWC (1972) Talc-kyanite-quartz schists and other 
high-pressure assemblages from Zambia. Mineral Mag $38: 837-846$

Wang X, Liou JG, Mao HK (1989) Coesite-bearing eclogites from the Dabie Mountains in central China. Geol 17:1085-1088

Whelan JF, Rye RO, DeLorraine W (1984) The Balmat-Edwards zinc-lead deposits-synsedimentary ore from Mississippi Valleytype fluids. Econ Geol 79:239-265

Wickham SM, Taylor HP Jr (1985) Stable isotopic evidence for large-scale seawater infiltration in a regional metamorphic terrane; the Trois Seigneurs Massif, Pyrenees, France. Contrib Mineral Petrol 91:122-137

Wilson AF, Green DC (1971) The use of oxygen isotopes for geothermometry of Proterozoic and Archaean granulites. Spec Publ Geol Soc Aust 3:389-400

Wilson AF, Green DC, Davidson LR (1970) The use of oxygen isotope geothermometry on the granulites and related intrusives, Musgrave Ranges, Central Australia. Contrib Mineral Petrol $27: 166-178$

Yang J, Smith DC (1989) Evidence for a former sanidine-coesite eclogite at Lanshantou, eastern China and the recognition of the Chinese "Su-Lu Coesite-eclogite Province". Terra Abstra 1:26

Editorial responsibility: V. Trommsdorff 